\title{
A wolf in sheep's clothing
}

\author{
Harold G. Roberts, MD, Lawrence M. Wei, MD, and Vinay Badhwar, MD
}

\author{
From the Department of Cardiovascular and Thoracic Surgery, West Virginia University, Morgantown, WVa. \\ Disclosures: The authors have nothing to disclose with regard to commercial support. \\ Received for publication Sept 6, 2017; accepted for publication Sept 8, 2017; available ahead of print Oct 15 , \\ 2017. \\ Address for reprints: Vinay Badhwar, MD, Department of Cardiovascular and Thoracic Surgery, West Virginia \\ University, 1 Medical Center Dr, Morgantown, WV 26506-8059 (E-mail: vinay.badhwar@wvumedicine.org). \\ J Thorac Cardiovasc Surg 2018;155:e23-4 \\ $0022-5223 / \$ 36.00$ \\ Copyright (C) 2017 by The American Association for Thoracic Surgery \\ https://doi.org/10.1016/j.jtcvs.2017.09.026
}

In the current issue of the Journal, Bringmans and colleagues ${ }^{1}$ laudably report a fatal case of an atrioesophageal fistula (AEF) after stand-alone epicardial ablation (EA) of persistent atrial fibrillation with a radiofrequency (RF) device. The hypothesized thermal injury mechanism was from heating of an atrial septal occluder device implanted years earlier. Although Bringmans and colleagues $^{1}$ used an RF pen on the back wall of the left atrium, they surmise that injury may have been associated with clamp use near the atrial septal occluder. After the minimally invasive EA procedure, the patient presented with a delayed diagnosis of AEF and died.

This highlights a few important elements. First, the transparency of Bringmans and colleagues ${ }^{1}$ exemplifies their leadership in the field of surgical ablation. A report of excellent results teaches us what is achievable. A report of poor results teaches us what is to be avoided to advance the field. Second, to embrace the explanation by Bringmans and colleagues ${ }^{1}$ of the unusual etiology of this rare or never event, we must discount the existence of alternatives. Third, the case of Bringmans and colleagues ${ }^{1}$ illustrates a known peril of EA and should stimulate a root cause analysis for its avoidance. Root cause is defined as a nonconformance factor that should be permanently eliminated though process improvement.

Transcatheter atrial septal occluder devices have a long experience. They are known often to become so well incorporated with endothelialization and fibrosis that magnetic resonance imaging is permitted. ${ }^{2}$ The occurrence of AEF after EA with thermal devices, however, is a known yet devastating complication with clear causality. $^{3,4}$

Thermal dispersion away from the electrode-blood-tissue interface is inherent with epicardially applied RF, with as much as $38 \%$ of delivered power reaching nontarget tissues. $^{5-7}$ Bipolar clamps are known to deliver acceptable transmurality but may be difficult to apply in minimally invasive lesions. Unipolar RF devices and bipolar RF pens tend to dissipate heat, with transmurality rates under $80 \%$. $^{7}$ As Bringmans and colleagues ${ }^{1}$ dutifully describe,

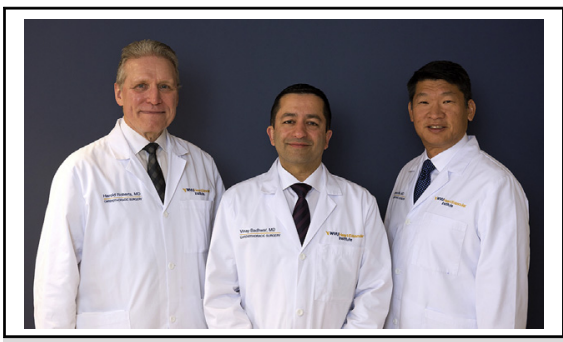

Left to right. Harold G. Roberts, MD, Vinay Badhwar, MD, and Lawrence M. Wei, MD

\section{Central Message}

Stand-alone surgical ablation of atrial fibrillation must be safe and longitudinally effective therapy. It is time to reevaluate whether epicardial radiofrequency ablation can hold true to this goal.

See Article page e19.

the epicardial RF pen has been implicated in 8 known left atrial perforations since 2008. A group including one of the authors of this case report ${ }^{8}$ recently reported their experience in 64 patients with a 23-month success rate off antiarrhythmic drugs of $67 \%$ and a $20.3 \%$ complication rate, including 2 left atrial perforations. The recent emergence of the convergent procedure, involving RF EA without appendage obliteration, has introduced similar complications, including a report by highly experienced operators of $1 \mathrm{AEF}, 2$ strokes, and 3 deaths in just 24 patients. $^{9}$

Not everyone is as honorable as Bringmans and colleagues. ${ }^{1}$ Ever-increasing softly spoken accounts of unpublished perforations are now reaching the point of becoming a clearly detectable signal in the noise.

The impetus for developing off-pump EA technology has been the perceived perils of cardiopulmonary bypass. However, the intimation that EA is "safer" than open surgical ablation is challenged by several large series of minimally invasive Cox maze IV procedures with endocardial cryothermy, demonstrating an efficacy upwards of $90 \%$ with negligible mortality, very low morbidity, and virtually no instances of collateral tissue damage. $3,10,11$ The recent abrupt suspension of the Pivotal Study of a Dual Epicardial and Endocardial Procedure (DEEP) Approach may serve as further corroborative evidence that EA may have escalating safety issues. 
With evidence mounting, has the implied promise of the safety of EA performed with pens or wands become a veritable wolf in sheep's clothing? In a specialty that embraces technology to advance quality and patient safety, it is incumbent upon us to root out potential factors of nonconformance before someone else does it for us. ${ }^{12}$

\section{References}

1. Bringmans T, Verrijcken A, La Meir M, Rega F. Atrioesophageal fistula after epicardial ablation for atrial fibrillation. J Thorac Cardiovasc Surg. 2018;155: e19-21.

2. Foth R, Quentin T, Michel-Behnke I, Vogt M, Kriebel T, Kreischer A, et al. Immunohistochemical characterization of neotissues and tissue reactions to septal defect-occlusion devices. Circ Cardiovasc Interv. 2009;2:90-6.

3. Je HG, Shuman DJ, Ad N. A systematic review of minimally invasive surgical treatment for atrial fibrillation: a comparison of the Cox-maze procedure, beating-heart epicardial ablation, and the hybrid procedure on safety and efficacy. Eur J Cardiothorac Surg. 2015;48:531-40; discussion 540-1.

4. Bhaskaran A, Chik W, Thomas S, Kovoor P, Thiagalingam A. A review of the safety aspects of radio frequency ablation. Int J Cardiol Heart Vasc. 2015;8: 147-53.
5. Berjano EJ, Hornero F. What affects esophageal injury during radiofrequency ablation of the left atrium? An engineering study based on finite-element analysis. Physiol Meas. 2005;26:837-48.

6. Wittkamph F, Nakagawa H. RF catheter ablation: lessons on lesions. Pacing Clin Electrophysiol. 2006;29:1285-97.

7. Melby SJ, Schuessler RB, Damiano RJ Jr. Ablation technology for the surgical treatment of atrial fibrillation. ASAIO J. 2013;59:461-8.

8. de Asmundis C, Chierchia GB, Mugnai G, Van Loo I, Nijs J, Czapla J, et al. Midterm clinical outcomes of concomitant thoracoscopic epicardial and transcatheter endocardial ablation for persistent and long-standing persistent atrial fibrillation: a single-centre experience. Europace. 2017;19:58-65.

9. Edgerton Z, Perini AP, Horton R, Trivedi C, Santangeli P, Bai R, et al. Hybrid procedure (endo/epicardial) versus standard manual ablation in patients undergoing ablation of longstanding persistent atrial fibrillation: results from a single center. J Cardiovasc Electrophysiol. 2016;27:524-30.

10. Ad N, Henry L, Friehling T, Wish M, Holmes SD. Minimally invasive stand-alone Cox-maze procedure for patients with nonparoxysmal atrial fibrillation. Ann Thorac Surg. 2013;96:792-8; discussion 798-9.

11. Ad N, Damiano RJ Jr, Badhwar V, Calkins H, La Meir M, Nitta T, et al. Expert consensus guidelines: examining surgical ablation for atrial fibrillation. J Thorac Cardiovasc Surg. 2017;153:1330-54.e1.

12. Williams EA, Nikolai de A, Ladwig L, Miller C, Fredeboelling E. Development of "SWARM" as a model for high reliability, rapid problem solving, and institutional learning. Jt Comm J Qual Patient Saf. 2015;41:508-13. 